UDC 81'255.4+325.8(477)

DOI https://doi.org/10.32838/2710-4656/2021.1-2/47

Lychuk S. $V$.

Ivano-Frankivsk National Medical University

\title{
TRANSLATION AS A FORM OF LITERARY RELATIONSHIP OF UKRAINE DURING ITS INDEPENDENCE (2000-2013)
}

The article is devoted to the problem of the translation of works Ukrainian poets and writers into English. The situation is analyzed of book typography and edition Ukrainian in Europe and abroad in the period from 2000 to 2013. The tendency is described in the flow of translations from the Ukrainian to foreign languages after Ukraine's independence and are defined some prospects for the development of this activity. Conditionally independence is divided into three publishing periods. The first period of 1991-1999 was the beginning of the formation and development of independent Ukraine. The second period - 2000-2013. The third period - 2014 and to this day. The work is filled with the names of prominent Ukrainians, who create Ukrainian and translators who serve and can serve as the basis for the future strategy of popularizing Ukrainian works abroad. The important role was noted in the dissemination of high quality translation literature by publishing houses. The literature of this period is classified according to the genres in chronological order. No less important factor in the presentation of the Ukrainian word is the direct participation of the artists themselves in various cultural events, festivals and open reading. The review and analysis of translations Ukrainian literature in English during this period shows that the acquisition of the English-language reader by the translated products of Ukrainian origin is gradual, but too slow and insignificant. The successful strategy for popularizing Ukrainian literary works depends on the mechanisms by which translation and publication of Ukrainian works takes place. It is worth noting the quality of translation of a high artistic level. At the same time, the quality of printing and design is improved, and the development of computer technology enables the publication of electronic publications.

Key words: Ukrainian literature, translation, foreign publications, publisher, publishing house, genre, cultural events.

Introduction. Today Ukraine is at an important stage in finding its place in the new system of the international community, in the process of developing new relations with European structures. Geopolitically while staying in the centre of Europe with the states which are actively rebuilding their economies, Ukraine is significantly behind and lagging behind the processes taking place in the neighbouring European countries and beyond, including translation activities.

Translation is an indispensable means of spreading literary works and ideas in other languages and in other cultures, including Ukrainian. Literary translation is a creative act, it is much more than just a tool for transferring text from one language to another. The translations of any language and culture are the key to continuous enrichment. Various historical events and translations are interconnected: the criteria for translations are historically different, and translations play different roles in different historical moments. Given the fact that modern Ukraine is experiencing a historical moment, the urgency of popularizing the source language for translation is special.
Conditionally independence can be divided into three publishing periods. The first period of 1991-1999 was the beginning of the formation and development of independent Ukraine, the formation of new information flows, including translations. The formation of the legislative base of its own economy on a new basis and other factors could not but affect the state of national publishing (the release of translations is in decline).

The second period - 2000-2013. The upper limit is due to the turning point of the end of 2013 - start 2014: the "Revolution of Attitude", "hybrid war" with a powerful informational component.

The third period - 2014 and to this day. At the beginning of 2014, the implementation of many state target programs was stopped, including those aimed at creating a powerful system of informing about domestic publishing products, as well as the system of state grants for the publication of works translated into Ukrainian and from the Ukrainian language into foreign languages (for 2014-2018) [6].

The theoretical principles of translation studies are highlighted in the works of the classics this science: 
L. Barkhudarov, V. Vinogradov, G. Yeger, L. Latishev, V. Komisarov, Yu. Naida, Y. Otscker, O. Fedorov, O. Schweitzer et al. Contemporary working out in this field of knowledge are I. Alekseyeva, M. Garbovsky, D. Yermolovich, T. Kazakova, I. Markoviniy, L. Nelyubin, A. Selivanova, V. Sdobnikov, Y. Sorokin, O. Petrova and others. Special attention was paid to the culture of the language translation by the theorists and practitioners of the Ukrainian translation O. Kundzich, S. Kovhanyuk, V. Koptilov, M. Rylsky, O. Finkel and others. In the work "Translation Practice" S. Kovhanyuk considered the question of the translator's creative personality, peculiarities of the translation of poetic works [4]. Many theoretical and practical questions are given in the textbook "Translation Studies (German-Ukrainian Direction)", by the authors T. Kyiak, A. Naumenko and O. Oguy [3].

Abroad contemporary Ukrainian literature are being explored Marco Pavlyshyn (Australia), Marco Andreichik (Canada), Olga Hnatiuk and Lidia Stefanivska (Poland), Vitaliy Chernetskiy (USA), Stefan Simonek (Austria), William Bleker (Great Britain) and also Alexander Krotohwil (Germany), Pavel Romanyuk (Romania) etc.

Our research provides a short overview of the development of the translation Ukrainianlanguage sources in the dominant world language in English. As for the translation of fiction, English is predominant $(30.8 \%)$, so we chose this particular language [7, p. 125].

The purpose of the article is to analyze the state of the translation of Ukrainian literature in English from 2000 to 2013 and determined the prospects for the development of this activity.

The only one today a complex research of the flow of translations into Ukrainian and Ukrainian from foreign languages that was conducted for the first time since the independence of Ukraine was carried out within the framework of the "Book-Platform" project and covers the period from 1991 to $2012[9 ; 10 ; 11]$.

Our work is filled with the names of prominent Ukrainians, who create Ukrainian and translators who serve and can serve as the basis for the future strategy of popularizing Ukrainian works abroad.

R. Kindlerova, a Czech translator from the Ukrainian language, emphasizes that every literature should be written primarily for its reader. And if there's a work that goes beyond the scope of national literature, then it's good: there's something to translate [8].

According to V. Danilenko Ukrainian literature exists on a horizontal model, that is, the role of the capital is not decisively important for the success of the writer. This is evident, in particular, from the fact that some of the most famous Ukrainian writers such as Yuri Andrukhovich, Taras Prokhasko, Yuriy Izdryk and Serhiy Zhadan are not from Kyiv and do not reside in it [1].

Ukrainian literature does not know the boundaries. It is printed all over the world. Translations of Ukrainian artists are read in English, French, German, Polish, Czech, Serbian, Armenian, Georgian, Norwegian, Swedish and other languages.

\section{Translations of Ukrainian works in English}

Trends in the development of the translation process of national literature in English are primarily due to historical and political factors. The nature of Ukrainian translations is clearly defined by geographical principle: English translations done on the territory of the European continent and it beyond. It is clear that the advantage does not belong to Europe, as it is in the United States of America, Canada, and Australia that powerful research centres and centres of Ukrainian studies exist thanks to the efforts of Ukrainian intellectuals of post-war emigration. Of course, the number of translators of Ukrainian literature in different countries is different.

The significant part of the presentation of Ukrainian literature in the English-speaking world is a some of British translators. Among of them we note Vira Rich, Stephen Komarnicki, Tom Moor, Sara Luksach, Robert Gemison and others. The most well-known authors of the translations of Ukrainian literature outside Europe are Maria Skrypnyk, Virliana Tkach, Yuri Tkach, Vitaly Chernetsky, Roma Franko, Bogdan Boichuk, Marko Andreichik and others. As noted by Maxim Tarnavsky, the history of Ukrainian literature translations in English is rather short and uneven (Maxim Tarnawsky, 2004).

In the first years of independence of our country, Ukrainian literature was very rarely published in English outside of Europe. The exception is the printed works of the most famous Ukrainian classics Taras Shevchenko, Lesya Ukrainka, Ivan Franko and several other writers. In the UK, by the year 2000, no Ukrainian book was published in English. Although one of the most prominent British translators of Ukrainian literature Vira Rich successfully worked on a field of poetic translation, whose texts were published abroad and published in periodicals [5, p. 207-228].

The situation has changed in the beginning of the XXI century. In the period from 2000 to 2013, 20 work translations of Ukrainian contemporary fiction in English were published in the UK. The 
publications are published in the leading British publishing house "Vintage" (9 books) and "Harvill Secker" (6 books), "The Harvill Press" (1 book), Retailer (1 book), "Glagoslav" (3 books).

During this period, of course, quantitative predominance of translations, were published in the USA, Canada and Australia, over translations published in Europe [9].
The works translated in the UK, designed primarily for a wide reader's audience, they cover the intellectual psychological prose, written in the genre of detective adventure novel-thriller and family drama. The fragment of the works published in this country is given in Table 1.

Note that the collection of poems by Pavlo Tychyna "Poetry Salzburg" in the translation of Stiven

Table 1

\begin{tabular}{|c|c|c|c|}
\hline $\begin{array}{c}\text { The author } \\
\text { of the work }\end{array}$ & Translator & The name of the work & Year of publication \\
\hline Andriy Kurkov & $\begin{array}{c}\text { Amanda Lav Darraf, } \\
\text { Endriy Bromfild, George } \\
\text { Berd }\end{array}$ & $\begin{array}{c}\text { "Death of Stranger" } \\
\text { "The game with a clipped finger" } \\
\text { "Picnic on Ice" } \\
\text { "The Companion of the Dead" } \\
\text { "The last president's love" } \\
\text { "The Night Milk" }\end{array}$ & $\begin{array}{c}2001,2003,2010 \\
2003,2009 \\
2004,2005,2010 \\
2005,2010 \\
2007,2009 \\
2011\end{array}$ \\
\hline Larisa Denisenko & $\begin{array}{c}\text { Maykl Naydan, } \\
\text { Svitlana Barns }\end{array}$ & $\begin{array}{c}\text { The Penguin Novels } \\
\text { "Sarabanda gang Sari" }\end{array}$ & 2006 \\
\hline Maria Matios & Yuriy Tkach & "Almost never the Reverse" & 2013 \\
\hline Iren Rozdobudko & $\begin{array}{c}\text { Maykl Naydan, } \\
\text { Olga Titarenko }\end{array}$ & $\begin{array}{c}\text { "Lost Button" } \\
2012\end{array}$ \\
\hline Pavlo Tychyna & Stiven Komarnicki & $\begin{array}{c}\text { "Poetry Salzburg" } \\
\text { "The Sorrow Mother" }\end{array}$ & 2012 \\
\hline
\end{tabular}

Table 2

\begin{tabular}{|c|c|c|c|c|}
\hline & The author of the work & Translator & The name of the work & $\begin{array}{c}\text { Year } \\
\text { of publication }\end{array}$ \\
\hline \multirow[t]{3}{*}{ Monolingual edition } & Ivan Franko & Ivan Teply & $\begin{array}{l}\text { Collection of poems } \\
\text { "Fallen leaves" }\end{array}$ & 2009 \\
\hline & $\begin{array}{c}\text { Lyubko Deresh, Irena } \\
\text { Karpa, Katerina Hinkulova, } \\
\text { Svitlana Pyrkalo, Ostap } \\
\text { Slivinsky }\end{array}$ & & Anthology "Laid Half" & 2009 \\
\hline & Zirka Mentazyuk & & "Kyiv fairy tales" & 2006 \\
\hline \multirow[t]{9}{*}{$\begin{array}{l}\text { Bilingual editions } \\
\text { of individual writers }\end{array}$} & Pavlo Tychyna & \multirow{6}{*}{ Maykl Naydan } & "Early Lyrics" & 2000 \\
\hline & Yuriy Vynnychuk & & $\begin{array}{l}\text { "Windows of the frozen } \\
\text { time" }\end{array}$ & 2000 \\
\hline & Lina Kostenko & & "Landscapes of Memory" & 2002 \\
\hline & Victor Neborak & & $\begin{array}{l}\text { "The Flying Head } \\
\text { and Other Poetry" }\end{array}$ & 2005 \\
\hline & Bogdan Igor Antonych & & "Great Harmony" & 2007 \\
\hline & Maxim Rylskiy & & "Autumn Stars" & 2008 \\
\hline & Volodymyr Tsybulko & Yuri Tarnavsky & $\begin{array}{l}\text { "Angels in the pyramid", } \\
\text { "The Eye on the Bell } \\
\text { Tower" }\end{array}$ & $\begin{array}{l}2001 \\
2005\end{array}$ \\
\hline & Taras Shevchenko & Vira Rich & $\begin{array}{c}\text { "Selected poetry. } \\
\text { Painting. Graphics" }\end{array}$ & 2007 \\
\hline & Vasyl Gabor & $\begin{array}{l}\text { Patrick Cornes, } \\
\text { Natalia Pomirko, } \\
\text { Oksana Bunio } \\
\end{array}$ & $\begin{array}{l}\text { "The Book of Exotic } \\
\text { Dreams and Real Events" }\end{array}$ & 2012 \\
\hline \multirow[t]{2}{*}{ Bilingual anthologies } & & $\begin{array}{l}\text { Virliana Tkach, } \\
\text { Vanda Phipps }\end{array}$ & "In Another Light" & 2008 \\
\hline & & $\begin{array}{l}\text { Maykl Naydan } \\
\text { and others }\end{array}$ & "100 years of youth" & 2008 \\
\hline
\end{tabular}


Komarnicki was published in Austria in 2012, and the poem "Grieving mother" - in four languages: English, French, Georgian and Russian.

The works published and issued in the US, Canada, or Australia, differ in their diversity of genres: prose, dramatic, poetic texts, samples of classical and contemporary fiction, children's, religious and theological (humanitarian) literature.

Among publications of the works of Ukrainian literature in English are those that were published in Kyiv and Lviv. This publication is a separate author, one-way and bilingual anthologies.

If we analyze the translations of Ukrainian contemporary and classical literature in English, published outside of Europe, then they are characterized by greater completeness and diversity of writers' personalities.

Let's be specific the anthology of selected stories of Ukrainian classics translated by Romy Franko. Among them: selected small prose by Gritsk Hryhorenko, Olga Kobilyanska, Natalia Kobrynska, Olena Pchilka, Lesya Ukrainka, Lyubov Yanovska, Eugenia Yaroshynska (2000), selected prose by Anatoliy Dymarov, Yevhen Gutsal and Olena Zvychaina (2002), selected prose by Stepan Vasilchenko, Mikhail Zhuk, Mikhail Kotsyubinsky, Osip Makovey, Yevhen Mandichevsky, Ivan Franko, Hnat Khotkevych, Mykola Cherniavsky, Sylvester Yarychevsky and others (2004), selected prose by Sidor Vorobkevych, Boris Grinchenko, Alexander
Konysky, Panteleimon Kulish, Bohdan Lepky, Yuri Fedkovych, Ivan Franko, Hnat Hotkevych, and Oleksa Storozhenko (2008).

We cannot ignore the bilingual edition of Vasil Makhno's poem "Thread and Selected New York Poems" translated by Orest Popovych (2009). The bilingual anthology of poetry "Modern Poetry of Ukraine and Australia" (2011) deserves great attention, which includes translations of texts of many modern masters of the Ukrainian word: Yuri Andrukhovych, Katerina Babkina, Natalka Bilotserkivets, Mirek Bodnar, Galina Gevka, Pavlo Hirnyk, Mikhail Grigoriv, Sergei Zhadan, Oksana Zabuzhko, Yuriy Zavadsky, Oleg Kotsarev, Oleg Lishega, Petr Midianko, Victor Neborak, Grigory Semenchuk and Irina Shuvalova.

The tremendous work is the trilingual (Ukrainian, Russian and English) anthology of the poetry of Igor Pavlyuk and Yuri Lazirk "Catching the Webbirds" (2011).

The selected poetic and prose texts of Grigory Chubay performed by Taras Chubay (2008) included to the original series of booklets "Modern Ukrainian Literature" in the translation of Mark Andreichik, Yuri Andrukhovych, Viktor Neborak (2009), Sergei Zhadan, Taras Prokhasko (2010) and Vasyl Gabor (2012).

The basis and quantitative characteristics of book publications of Ukrainian literature in English in the Europe and beyond are presented in chronological order for the period from 2000 to 2013 (relatively better than 1991-1999).

Table 3

\begin{tabular}{|c|c|c|c|}
\hline The author of the work & Translator & The name of the work & $\begin{array}{c}\text { Year } \\
\text { of publication }\end{array}$ \\
\hline Volodymyr Vynnychenko & Theodor Procopiv & $\begin{array}{c}\text { "Selected Stories", } \\
\text { "Notes of the Mephistopheles" }\end{array}$ & $\begin{array}{l}2001 \\
2001\end{array}$ \\
\hline Olga Kobylyanska & Mariya Skrypnyk & "On Sunday it was digging potion early" & 2001 \\
\hline Anatoliy Dimarov & Roma Franko & "The Wounded Wings" & 2001 \\
\hline Lidia Paliy & Roma Franko & "Woman in the Window" & 2002 \\
\hline Igor Klech & Maykl Naydan & "Earth is Binocular Extent" & 2004 \\
\hline Yuri Andrukhovich & Maykl Naydan & $\begin{array}{l}\text { "Perverzia", } \\
\text { "Moscoviada" }\end{array}$ & $\begin{array}{l}2005 \\
2008\end{array}$ \\
\hline Yurko Izdryk & Marco Pavlyshyn & "Wozzeck" & 2006 \\
\hline \multirow{3}{*}{ Oksana Zabuzhko } & Askold Melnychuk & $\begin{array}{l}\text { "Girls", } \\
\text { "Milena" }\end{array}$ & $\begin{array}{l}2005 \\
2006\end{array}$ \\
\hline & Galina Grin & "Field Study of Ukrainian Sex" & 2011 \\
\hline & Nina Shevchuk-Murray & "Museum of Abandoned Secrets" & 2012 \\
\hline Alexander Dovzhenko & Dzvini Orlovska & "Enchanted Desna" & 2006 \\
\hline Ivan Franko & Roma Franko & $\begin{array}{l}\text { "For a home hearth", "Fundamentals } \\
\text { of the public", "Without asking ford", } \\
\text { "Lel and Polel", "Crossroads" }\end{array}$ & 2006 \\
\hline Fedir Odrach & Erma Odrach & “The Wave of Fear" & 2008 \\
\hline Bogdan Igor Antonich & Maykl Naydan & "Ecstasy and Elegy" & 2011 \\
\hline Dmytro Pavlychko & Maykl Naydan & "Two Colors of the Soul" & 2012 \\
\hline
\end{tabular}


Table 4

\begin{tabular}{|c|c|c|}
\hline $\begin{array}{c}\text { Year } \\
\text { of publication }\end{array}$ & $\begin{array}{c}\text { Number } \\
\text { of publications } \\
\text { outside of Europe }\end{array}$ & $\begin{array}{l}\text { Number } \\
\text { of editions } \\
\text { in Europe }\end{array}$ \\
\hline 2000 & 2 editions & - \\
\hline 2001 & 5 editions & 1 edition \\
\hline 2002 & 3 editions & - \\
\hline 2004 & 3 editions & 2 editions \\
\hline 2005 & 2 editions & 2 editions \\
\hline 2006 & 7 editions & 1 edition \\
\hline 2007 & - & 1 edition \\
\hline 2008 & $\begin{array}{c}5 \text { editions, } \\
\text { among them - } \\
1 \text { anthology }\end{array}$ & - \\
\hline 2009 & 2 editions & 3 editions \\
\hline 2010 & 1 edition & 3 editions \\
\hline 2011 & 3 editions & 1 edition \\
\hline 2012 & 3 editions & 4 editions \\
\hline 2013 & 1 edition & 1 edition \\
\hline
\end{tabular}

The Ukrainian publications (for the same period) were classified by genre according to the research of the Next Page Fund within the framework of the Book Platform project. Among them we will mean the following: contemporary fiction 36 editions, including 2 - anthologies, the rest - book editions; classical fiction - 11 editions, including $6-$ anthologies, 5 - separate book editions; humanities and social sciences -13 editions, of which literary works -5 , historical and philosophical -7 , social -1 ; children's literature -3 editions; drama -1 edition; modern poetry -7 editions, including -2 anthologies, 3 - two- and 1 - third lingual editions, 3 - separate poetry compilations; religious and theological literature -2 editions; popular science literature - no edition; classical poetry - no edition.

The most famous translators and their merit in translation

Given the foregoing, it is probably appropriate to identify one of the most important question of the working conditions of translators of Ukrainian literature in English. There is no doubt that, first of all, the government headed by the government should be interested in spreading their own national culture and literature, in particular, beyond its borders. Unfortunately, the cultural policy of the state has taken a passive position, compared with other countries. The most translations are the initiative of public and private organizations or individuals.

Despite the minimal number of translators of Ukrainian literature in Europe and abroad, they still have the most meaningful value.

It is worth noting the undeniable and the most important role of promoting Ukrainian literature to its translators: Patrick Cornes, Mark Mavlishin, Askold Melnychuk, Michael Naydan, Ulyana Pasichnyk, Virliana and Yuri Tkach, Vanda Phipps, Roma Franko, Vitaliy Chernetsky; from the younger generation Mark Andreichik, Martha Bazyuk, Olena Jenning, Dzvinka Orlovsky and others.

Vera Rich in the UK and Michael Naydan in the United States deserve praise and honour who work tirelessly in the field of translation, translating the works of Ukrainian writers into English.

Vera Rich translated a works of many Ukrainian poets known in the world. Among them we can name Lina Kostenko, Lesya Ukrainka, Taras Shevchenko, Ivan Franko, Olena Teliga, Vasyl Symonenko, Vasyl Stus and others. Among the artistic translations we will mention the complete collection of Taras Shevchenko's poems (2008) and a solid anthology of Ukrainian poetry of the XX century "One Hundred Years of Youth" (2000), translated with Michael Naydan (USA).

Ukraine is also represented by a series of authoritative presentations by Vera Rich entitled "Ukraine: From Mazepa to Maidan" at the universities of Great Britain (Oxford, Cambridge) and the International Literary Festival in Edinburgh (Scotland), 2007 [2, p. 186-187].

Thanks to translations by Stiven Komarnitsky in the UK, read works by Pavlo Tychyna, Bogdan Igor Antonych, modern poet Igor Pavlyuk etc., and Sarah Luksach - Yuri Andrukhovych, and Andriy Kurkov - George Berd, Andrew Bromfield and Amanda Lav Darraf.

Thus, the most productive work in the United States, the popularization of many works of Ukrainian poets and writers is associated with the name of Michael Naydan. He is the author of the translation of the collection of stories by Yuri Vinnichuk (2000), Lina Kostenko (2002), Igor Kleha (2004), Bogdan Igor Antonych (2010, 2007), Victor Neborak (2005), Maxim Rylsky (2008), Yuri Andrukhovich's novel "Perverzia" (2005), lyric Dmitro Pavlychko (2012), co-writer of novels Iren Rozdobudko (2012) and Larisa Denisenko (2013). He prepared translations of the novel Maria Matios "Sweet Darusia", prose by Yuri Vinnichuk, lyric by Atilla Mohyla, an anthology of poetic texts "Masterworks of Ukrainian Poetry". Irish poet and translator Tom Moore, translating poems by Igor Pavlyuk, and Scottish poet and translator Robert Gemison - poems by Nikolai Vorobiev, Vasyl Goloborodko, Oleg Lishega, Igor Rymaruk and others popularized Ukrainian literature in the European English-speaking environment.

From other translators the name of Larysa Onyshkevich-Zaleska deserves attention. She is a compiler and an author of the preface and the co-writer 
of the anthology of dramatic works "An Anthology of Modern Ukrainian Drama" (2012), writers of the senior and younger generation Patrick Cornes, Askold Melnychuk, Ulyana Pasichnyk, Yuriy Tkach, Virliana Tkach, Vanda Phipps, Roma Franko, Mark Andreichik, Olena Jenning, Dzvina Orlovsky and others.

Conclusions. The review and analysis of translations of Ukrainian literature in English in the period 2000-2013 shows that the mastery of English-language readers of translated products of Ukrainian origin is gradual but too slow and little noticeable. However, in comparison with the period of 1991-1999, the translation of Ukrainian literature into English is developing, certain positive tendencies are noticeable. It is worth noting the quality of translation of a high artistic level. At the same time, the quality of printing and design is improved, and the development of computer technology enables the publication of electronic publications.

Such a slow process, in our opinion, is due to a number of key factors. The lack of a well thoughtout humanitarian policy that would activate various forms of promotion of Ukrainian literature in the English-speaking world at the state level. Passive behaviour of state institutions - Ministry of Culture,
Ministry of Education, Science, Youth and Sports. Establishment of close forms of international cooperation in the field of culture and art (literature) and writers, translators in significant events and events of cultural life of Ukrainians. Lack of financial support for the implementation of various translation projects. Lack of Ukrainian specialists in the field of artistic translation. Enrichment of professional experience at the expense of international exchange between highly skilled translators in the field of artistic translation. Introduction of joint publishing projects and popularization of the achievements of classical and contemporary Ukrainian literature by their publication in such publications.

Of course, our article does not reflect the whole picture of the translation of works of Ukrainian writers, as well as not all the list of problems that hinder the rapid and qualitative translation of the masterpieces of Ukrainian literature.

In the future, research needs to be complemented and expanded with information on the market situation in other European country. We believe that it is also necessary to make selective spot research of genre blocks. It is also important to complement market research in the area of e-book publishing.

\section{References:}

1. Даниленко В. Лісоруб у пустелі: письменник і літературний процес. Академвидав. 2008. 346 с.

2. Дроздовський Д. Поетична історія України: погляд із туманного Альбіону. Всесвіт. 2007. № 5-6. С. 186-187.

3. Кияк Т. Р., Науменко А. М. та ін. Перекладознавство (німецько-український напрям) : підручник. Київ : Видавничо-поліграфічний центр «Київський університет». 2008. 543 с.

4. Ковганюк С. П. Практика перекладу: з досвіду перекладача. Київ : Дніпро. 1968. 275 с.

5. Косів Г. Віра Річ: Творчий портрет перекладача : монографія. Львів : Піраміда. 2011. 264 с.

6. Зоряна А. М. Документний потік перекладів українською та з української мови як відображення процесів міжкультурної комунікації (1991-2013 рр.) : дисертація на здобуття наукового ступеня кандидата наук із соціальних комунікацій за спеціальністю : 27.00.02 «Документознавство, архівознавство». Національна бібліотека України імені В. І. Вернадського. Київ. 2016.

7. Зоряна А. М. Документний потік перекладів як відображення міжкультурної комунікації : монографія. Київ : Нац. акад. керівних кадрів культури і мистецтв. 2017. 188 с.

8. Кіндлерова Р. Переклад як виклик і як... магія. ZN № 940, 12 квітня - 19 квітня 2013. URL: https:// dt.ua/CULTURE/rita-kindlerova-pereklad-yak-viklik-i-yak-magiya-_.html.

9. Поліщук Н. Переклади з української мови англійською мовою 1991 до 2012. 2013. URL: http://www. bookplatform.org/images/activities/425/ukrainianenglish_translationsstudy_ukr12.pdf.

10. Радулова Н., Генова Я., Антоненко А. Переклади з української після 1991 року. Факти, тенденції, рекомендації (резюме досліджень). URL: http://bookplatform.org/images/activities/53/translukr.pdf.

11. Родик К., Прихода М. та ін. Переклади на українську 1992-2012. URL: http://bookplatform.org/ images/activities/50/transintoukr.pdf.

\section{ЛИЧУК С. В. ПЕРЕКЛАД ЯК ФОРМА ЛІТЕРАТУРНИХ ВЗАЕМИН УКРАЇНИ В ПЕРІОД ЇЇ НЕЗАЛЕЖНОСТІ (2000-2013 РР.)}

Статтю присвячено проблемі перекладу творів украӥнських поетів та письменників на англійську мову. Проаналізовано становище книгодрукування та видання українських публікацій у Європі та за ії межами у період від 2000 до 2013 рр. Описано тенденцію у потоиі перекладів з украӥнської мови на іноземну після здобуття Україною незалежності та визначено деякі перспективи розвитку иієї 
діяльності. Умовно незалежсність поділено на три видавничі періоди. Перший період-1991-1999 роківбув початком становлення та розвитку незалежної України. Другий період - 2000-2013 роки. Третій період - 2014 рік і донині. Розвідка наповнена іменами визначних осіб, які творять украйнською, i перекладачів, які служать і можуть послужити основою майбутньої стратегії популяризації українських творів за кордоном. Відзначено важливу роль у поширенні якісної перекладної літератури видавництвами. Літературу иъьго періоду покласифіковано за жанрами у хронологічному порядку. Не менш вагомим фактором презентачії українського слова є безпосередня участь самих митиів у різноманітних культурних подіях, фестивалях та відкритих читаннях. Огляд й аналіз перекладів української літератури англійською мовою зазначеного періоду свідчить про те, щзо опановування англомовного читача перекладної продукиії українського походження поступове, але надто повільне і мало помітне. Успішна стратегія популяризації українських літературних творів залежить від механізмів, за допомогою яких відбувається переклад та публікації українських творів. Варто відзначити добротність перекладу високого художнього рівня. Водночас удосконалюється якість друку і дизайн, а розвиток комп 'ютерних технологій дає можливість публікації електронних видань.

Ключові слова: украӥнська література, переклад, закордонні публікаиії, видавець, видавництво, жанр, культурні події. 